\title{
Production and Partial Characterization of an Extracellular Phytase Produced by Muscodor sp. under Submerged Fermentation
}

\author{
Natálie Martins Alves', Luis Henrique Souza Guimarães², Roberta Hilsdorf Piccoli³, \\ Patrícia Gomes Cardoso ${ }^{*}$ \\ ${ }^{1}$ Department of Biology, Sector of Microbiology, Federal University of Lavras, Lavras, Brazil \\ ${ }^{2}$ Department of Biology, University of São Paulo, Ribeirão Preto, Brazil \\ ${ }^{3}$ Department of Food Science, Federal University of Lavras, Lavras, Brazil \\ Email: "patricia@dbi.ufla.br
}

Received 11 December 2015; accepted 19 January 2016; published 22 January 2016

Copyright (C) 2016 by authors and Scientific Research Publishing Inc.

This work is licensed under the Creative Commons Attribution International License (CC BY). http://creativecommons.org/licenses/by/4.0/

(c) (i) Open Access

\begin{abstract}
In most of the raw materials of plant origin used in animal feed, a portion of the phosphorus is stored as phytic acid or phytate. Phytate is the main storage form of phosphorus in vegetables but is not readily assimilated into food at low concentrations of the enzyme phytase. In addition to making phosphorous unavailable, phytate binds divalent cations such as calcium, copper, magnesium, iron, manganese and zinc, preventing the absorption of these nutrients in the gut of the animal. Phytase promotes the hydrolysis of the phytate phosphorus-releasing molecule, thereby increasing its bioavailability in feed. Phytase is distributed in plant and animal tissues and it is synthesized by some species of bacteria and fungi. The addition of this enzyme in the diet of animals is essential to promote greater uptake of phosphorus and also contributes to a decrease in the levels of phosphorus excreted by animals, thus reducing the pollution caused by excess phosphorus in the environment. This work aimed to select a fungus that stands out in the production of phytase among 100 isolates from Brazilian caves belonging to the genera Aspergillus, Penicillium and Cladosporium and 13 endophytic fungi of the aerial part of the coffee plant. For selection, the fungi were cultured in medium containing phytic acid as a sole source of phosphorus. After seven days at $25^{\circ} \mathrm{C}$, we evaluated growth and enzyme production by the presence of the phytic acid halo degradation (Enzymatic Index-EI) surrounding the colonies. Forty-seven species produced phytase, and the fungi Penicillium minioluteum (CF279) and Muscodor sp. (UBSX) showed higher degradation halos, 2.41 and 4.46, respectively. Considering the Muscodor sp. as the main source of phytase,
\end{abstract}

\footnotetext{
${ }^{*}$ Corresponding author.
}

How to cite this paper: Alves, N.M., Guimarães, L.H.S., Piccoli, R.H. and Cardoso, P.G. (2016) Production and Partial Characterization of an Extracellular Phytase Produced by Muscodor sp. under Submerged Fermentation. Advances in Microbiology, 6, 23-32. http://dx.doi.org/10.4236/aim.2016.61003 
high enzymatic levels were obtained when the fungus was grown under submerged fermentation with initial pH of 5.0 using wheat bran as additional carbon source for $144 \mathrm{~h}$, at $125 \mathrm{rpm}$ and $30^{\circ} \mathrm{C}$. Additionally, the enzyme was stable at $\mathrm{pH} 5.0$ and $40^{\circ} \mathrm{C}$, and inhibited $(14 \%-88 \%)$ by all compounds analyzed. Then, this is the first study that reports the production of phytase by the endophytic fungus Muscodor sp.

\title{
Keywords
}

\author{
Endophytic Fungus, Muscodor sp., Phosphorus, Phytase, Phytic Acid
}

\section{Introduction}

Phytic acid or phytate (myo-inositol hexakisphosphate) is the major source of phosphorus in animal feed, but animals cannot readily assimilate the element in this form. In addition to making the phosphorous unavailable, phytate binds to divalent cations $\left(\mathrm{Ca}^{+}, \mathrm{Cu}^{2+}, \mathrm{Mg}^{2+}, \mathrm{Fe}^{2+}, \mathrm{Mn}^{2+}\right.$ and $\left.\mathrm{Zn}^{2+}\right)$, preventing the absorption of these nutrients in the gut of the animals [1] [2].

In animal feed industries, the feed is usually supplemented with inorganic phosphate to meet the phosphorous needs for proper growth and development of animals. However, the anti-nutritional effects of phytate remain unaffected [3]. Excretion of indigestible phytate, resulting in a large amount of phosphorous in manure, leads to redistribution of phosphorous in the soil [4]. It may leach into waterways and cause eutrophication that generates water quality issues. Hence, elevated phosphorous levels in water and soil also create several environmental problems. To avoid phytate-related issues, there is a need to introduce methods for degradation of phytate. The physical and chemical methods are expensive and reduce the nutritional value of the feed as well. Therefore, enzymatic degradation of phytate is an important alternative [5].

Phytases (myo-inositol hexaphosphate phosphohydrolase; EC 3.1.3.8 and EC 3.1.3.26) are enzymes belonging to the class of phosphatases that hydrolyze phytic acid to myo-inositol phosphates and inorganic phosphate through a series of myo-inositol phosphate intermediates. This process eliminates the anti-nutritional characteristics of phytic acid. Phytases have potential applications in the food and feed industries. In recent years, phytases have attracted attention from researchers and entrepreneurs in the areas of nutrition, environmental protection and biotechnology. The annual sales of phytase in the USA were estimated to be $\$ 150$ million, which is one third of the entire enzyme market [5].

Microorganisms are the main sources of phytases with biotechnological potential with high performance, being used mainly in animal feed industry to eliminate the anti-nutritional properties of phytate [6] [7]. The production by yeast has been described in Saccharomyces cerevisiae, Candida tropicalis, Candida torulopsis, Debaryomyces castelii, Kluyveromyces fragilis and Schwanniomyces castellii [8]. They can also be produced by bacteria and filamentous fungi. The production by filamentous fungi has been described in Penicillium oxalicum PJ3, Schizophyllum commune, Rhizopus oryzae, Aspergillus ficcum and Rhizopus microspores var. microsporus [9]-[13]. Many studies are focused in the production and characterization of phytase from some microorganisms, but information concerning enzyme characteristics as regulation, catalytic capacity, specificity and optimization of production, still need to be clarified to reduce costs and to facilitate the use of this enzyme under an industrial scale. Commercially, phytases are produced by a limited number of microorganisms [14], what justify the importance to search new fungal strain as phytase producers. Then, this manuscript describes the prospection of fungal strains to produce extracellular phytase, the selection of the best producer and the optimization of some culture parameters to achieve high enzymatic production by the endophytic fungus Muscodor sp. This work is seminal in the reporting of phytase production by this fungus.

\section{Material and Methods}

The experiments were conducted in the Filamentous Fungi Genetics and Bioprospecting Laboratory-BIOGEN from Federal University of Lavras-UFLA, Lavras, Minas Gerais, Brazil and in the Laboratory of Microbiology from Faculty of Philosophy, Sciences and Letters of Ribeirão Preto, University of São Paulo-USP, São Paulo, Brazil. 


\subsection{Microorganisms Evaluated and Selection of Phytase-Producing Fungi}

One hundred filamentous fungi isolated from the Brazilian Caatinga caves and 12 endophytic fungi isolated from coffee plant (Coffea arabica L.) shoots, belonging to the Culture Collection of BIOGEN, were evaluated for their ability to produce phytases. The cultures were maintained in MilliQ water at $4^{\circ} \mathrm{C}$. The isolates were reactivated on potato dextrose agar (PDA) and incubated at $25^{\circ} \mathrm{C}$ for 7 days.

The selection of fungal phytase producers was carried out in medium containing (g/L) phytic acid $\mathrm{C}_{6} \mathrm{H}_{18} \mathrm{O}_{24} \mathrm{P}_{6}$ : 5; $\mathrm{NaNO}_{3}$ : 3; $\mathrm{MgSO}_{4} \cdot 7 \mathrm{H}_{2} \mathrm{O}: 0.5 ; \mathrm{KCl}: 0.5 ; \mathrm{FeSO}_{4}$ : 0.12; $\mathrm{CaCl}_{2}$ : 0.66; $\mathrm{ZnSO}_{4}: 0.17 ;$ agar: 30 [15]. The fungi that showed a clear zone (halo) around the colony and possessed an Enzyme Index (EI-halo diameter/colony diameter) greater than 2 were selected to evaluate the specific enzymatic activity.

\subsection{Molecular Identification}

The molecular identification of the selected fungi was carried out using sequences of the ITS region. The fungi were grown on PDA, and mycelium was scraped with a sterile toothpick. The extraction of total DNA was performed according to the "Mobio Ultra Clean Microbial ${ }^{\circledR}$ kit". Amplification reactions were performed in a volume of $30 \mu \mathrm{L}$ containing $15 \mu \mathrm{L}$ of Quiagen kit, $12 \mu \mathrm{L} \cdot \mathrm{H}_{2} \mathrm{O}, 10 \mathrm{pmol}$ primer F, 10 pmol primer R and 10ng DNA.

Primers were ITS1 (5’ TCCGTAGGTGAACCTGCGG 3’) and ITS4 (5’ TCCTCCGCTTATTGATATGC 5’) and amplification conditions were as follows: $95^{\circ} \mathrm{C} 2 \mathrm{~min}, 95^{\circ} \mathrm{C} 1 \mathrm{~min}, 50^{\circ} \mathrm{C} 1 \mathrm{~min}, 72^{\circ} \mathrm{C} 1 \mathrm{~min}$ and $72^{\circ} \mathrm{C} 7 \mathrm{~min}$, programmed for 35 cycles. The amplifications were performed in a thermocycler "MULTIGENE", Labnet International Inc. The sequences were analyzed with the aid of the SeqAssem program, and alignment with other sequences available in the "GenBank" database was performed by the MEGA program.

\subsection{Production of Extracellular Phytase under Submerged Fermentation (SF)}

The fermentation medium was prepared in $250 \mathrm{~mL}$ Erlenmeyer flasks by adding (g/L) of different additional carbon sources (wheat bran, soybean, sugarcane bagasse, oat, corn starch, and rye flour): 5, yeast extract: 3; $\mathrm{NaNO}_{3}$ : 3; $\mathrm{MgSO}_{4} \cdot 7 \mathrm{H}_{2} \mathrm{O}: 0.5 ; \mathrm{KCl}: 0.5 ; \mathrm{FeSO}_{4}$ : 0.12; $\mathrm{CaCl}_{2}: 0.66, \mathrm{ZnSO}_{4}: 0.17$, pH 5.5 [15], previously autoclaved at $120^{\circ} \mathrm{C}, 1.5 \mathrm{~atm}$ for $20 \mathrm{~min}$. Three mycelium disks of approximately $8 \mathrm{~mm}$ of the selected fungus (Muscodor sp.) were inoculated in the sterilized fermentation medium.

The influence of physical parameters on enzyme production and fungal growth as agitation (100, 125 and 150 $\mathrm{rpm})$, initial $\mathrm{pH}(4,5,6$ and 7$)$, temperature $\left(25^{\circ} \mathrm{C}, 30^{\circ} \mathrm{C}\right.$ and $\left.35^{\circ} \mathrm{C}\right)$ and incubation time $(24,48,72,96,120,144$ and $168 \mathrm{~h}$ ) were also analyzed.

After incubation, the cultures were filtered in vacuum Buchner funnel with Whatman filter paper $\mathrm{N}^{\circ} 1$ to give a cell free filtrate. The filtrate was dialyzed against distilled water for $24 \mathrm{~h}$ at $4^{\circ} \mathrm{C}$ and used for determining the extracellular enzymatic activity.

\subsection{Phytase Activity Assay}

Phytase activity was determined according to Gulati, Chadha and Saini [16]. The reaction medium was composed of $50 \mu \mathrm{L}$ of enzyme sample incubated with $50 \mu \mathrm{L}$ of phytic acid solution (dodecasodium hydrated $\mathrm{C}_{6} \mathrm{H}_{6}$ $\mathrm{Na}_{12} \mathrm{O}_{4} \mathrm{P}_{6} \cdot \mathrm{H}_{2} \mathrm{O}$ Sigma $\left.{ }^{\circledR}\right) 1 \%(\mathrm{w} / \mathrm{v})$, dissolved in sodium acetate buffer $0.2 \mathrm{M}, \mathrm{pH}$ 5.0. The reaction was performed at $40^{\circ} \mathrm{C}$ and then added with $100 \mu \mathrm{L}$ of $15 \%$ TCA (trichloroacetic acid) and $300 \mu \mathrm{L}$ distilled water in each test tube followed by addition of $0.9 \mu \mathrm{L}$ of the chromogenic reagent (of sulfuric acid $0.76 \mathrm{M}, 10 \%$ ascorbic acid and 2.5\% ammonium molybdate; 3:1:0.5 v/v/v). The tubes were then incubated at $50^{\circ} \mathrm{C}$ for $20 \mathrm{~min}$ and cooled down; after the reading was taken at $820 \mathrm{~nm}$ using a spectrophotometer. In each experiment we included inactivated enzyme controls to estimate the non-enzymatic hydrolysis of substrate. One unit of phytase activity was defined as the amount of phytase required to release one $\mu \mathrm{mol}$ of inorganic phosphorus (Pi) per minute under test conditions [13].

\subsection{Determination of Total Protein}

The total protein concentration was determined according to Bradford method [17] using bovine serum albumin (BSA) as standard. The amount of protein was expressed as $\mathrm{mg} / \mathrm{mL}$ of sample. Total protein (mg total) was calculated by multiplying the protein in $\mathrm{mg} / \mathrm{mL}$ for the sample volume. 


\subsection{Phytase Stability to Temperature and $\mathrm{pH}$}

The thermal stability was determined incubating the phytase samples in aqueous solution at $40^{\circ} \mathrm{C}, 50^{\circ} \mathrm{C}$ and $60^{\circ} \mathrm{C}$. After time intervals of 2, 5, 10, 15, 20, 30, 45 and $60 \mathrm{~min}$, aliquots were removed and maintained in an ice bath for phytase activity determination.

The $\mathrm{pH}$ stability of phytase was observed incubating the phytase samplesin citrate buffer $100 \mathrm{mM}(\mathrm{pH}$ 3, 4, 5 and 6). The enzyme and buffer were added at $1: 1(\mathrm{v} / \mathrm{v})$, and after incubation for $1 \mathrm{~h}$ at $25^{\circ} \mathrm{C}$, aliquots were removed and the relative enzyme activity was determined.

\subsection{Effect of Different Compounds on Phytase Activity}

The effect of different salts $(1 \mathrm{mM})\left(\mathrm{NaCl}, \mathrm{AlCl}_{3}, \mathrm{CuCl}_{2}, \mathrm{CuSO}_{4} \cdot 5 \mathrm{H}_{2} \mathrm{O}, \mathrm{FeCl}_{3}, \mathrm{HgCl}_{2}, \mathrm{KCl}, \mathrm{MgSO}_{4} \cdot 7 \mathrm{H}_{2} \mathrm{O}, \mathrm{Zn}\right.$ $\left(\mathrm{NO}_{3}\right) \cdot 7 \mathrm{H}_{2} \mathrm{O}$ and $\mathrm{CaCl}_{2}$ ), Urea and EDTA on phytase activity was investigated. The enzymatic reaction was performed as described above with addition of each compound. The results were expressed as relative activity (\%).

All experiments were performed in triplicate, using inactivated enzyme controls to estimate the non-enzymatic hydrolysis of substrate and taking into account the standard deviation for the construction of graphs.

\section{Results and Discussion}

Among the hundred fungi isolated from caatinga caves and twelve endophytic fungi qualitatively analyzed, 28\% were able to hydrolyze the phytic acid in the medium producing a clear halo. Among these strains phytase positive, 64.5\% showed an Enzyme Index (EI) lower than 2.0. Only six strains presented EI higher than 2, highlighting the endophytic fungus UBSX $(E I=4.41)$ and the cave fungus CF279 $(E I=2.41)($ Table 1$)$. These both strains were identified as Muscodor sp. (Xylariaceae, Ascomycetes) and Penicillium minioluteum, respectively, using molecular approach and the ITS region.

The enzymatic index of the enzyme produced by the endophyte Muscodor sp. had the highest value, so this isolate was chosen for phytase production under submerged fermentation. Muscodor sp. is a sterile (not producing spores) endophytic fungus possessing some interesting hyphal characteristics, including coiling, ropyness, and right angle branching. The mycelia of the fungus on most media are whitish and suppressed (Figure 1). The sequences were entered into "GenBank” as KJ425599.

Table 1. Production of phytase by endophytic fungi (UBSX, Z26 and HZM64) and by fungi isolated from caves (CF279, CF302 and HE189A).

\begin{tabular}{cc} 
Isolates & Index Value (EI) \\
\hline Muscodor sp. (UBSX) & 4.41 \\
Z26 & 4.35 \\
HZM64 & 3.7 \\
Penicillium minioluteum (CF279) & 2.41 \\
CF302 & 2.2 \\
HE189A & 2.09 \\
\hline
\end{tabular}
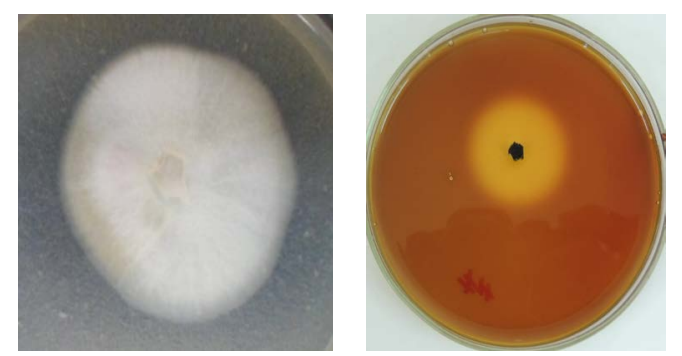

Figure 1. Mycelium of isolate Muscodor sp. (UBSX) grown on PDA (A) and halo of hydrolysis of the phytate by the phytase produced by the endophytic fungus Muscodor sp. (UBSX). 
The Muscodor genus has been reported as a good producer of several other metabolites of interest. Muscodor albus produces a mixture of volatile organic compounds (VOCs) which are lethal to a variety of human and plant pathogens, such as other fungi and bacteria. It is also effective against nematodes and certain insects [18]. Muscodor crispans (B-23) is an endophyte residing within the tissues of the stem of Ananas ananassoides, a wild pineapple of the Bolivian Amazon Basin. This fungus produces a number of esters, alcohols and acids of low molecular weight whose volatiles have antibiotic properties, making this a potentially useful organism in many contexts. Despite its $100 \%$ genetic similarity to regions of rDNA of M. albus, this organism is considered distinct because of the number and type of its unusual phenotypic characteristics [19]. According to our knowledge, this is the first time that the phytase production is reported for the genus Muscodor.

Investigation of new fungal strains as phytase producers is very important, allowing alternatives to produce enzymes with different properties than that produced by the genus Aspergillus, mentioned as the main fungal source of phytases, such as A. ficcum [20], A. fumigatus [21], A. terreus [19] and A. niger NCIM 563 [22].

The enzymatic production by microorganisms can be influenced by different conditions, including the nutrient sources available in the culture medium. Carbon and nitrogen sources are essentials for microbial growth and are determinants in the enzyme production. According to Table 2, the use of all additional carbon sources resulted in phytase production by Muscodor sp., especially using wheat bran ( $4.10 \mathrm{U} / \mathrm{mg}$ of protein). Wheat bran is a byproduct of wheat grain, and its composition is rich in calories, proteins, vitamins, minerals, and other important elements for the development of the microorganism and for the enzyme production, making it an excellent substrate for phytase production. The microorganism Mucor racemosus NRRL 1994 produced phytase using wheat bran as substrate/support [23]. Other additional complex carbon sources as crushed soy, as well as some saccharides as sucrose, glucose, fructose, galactose also have been investigated for phytase production [13]. The use of alternative carbon sources for phytase production can reduces the cost of process, allowing the obtainment of a cheap product.

\subsection{Influence of the Initial pH, Temperature and Agitation on Phytase Production}

The enzyme production by microorganism was affected by different culture conditions (Figure 2). Considering the influence of the initial $\mathrm{pH}$ of the culture medium, the peak of production of phytase by Muscodor sp. was obtained at pH 5.0 (Figure 2(a)) as well as observed for production of phytase by Aspergillus niger ATCC 9142 [24] and A. niger FS3 [25]. These results are in agreement with Vohra and Satyanarayana [26] that described the initial $\mathrm{pH}$ from 5.0 to 6.0 as characteristic for production of most microbial phytases.

According to the Figure 2(b), the agitation level also influenced the production of phytase by Muscodor sp. with maximal production obtained at $125 \mathrm{rpm}$. At $150 \mathrm{rpm}$, the fungal biomass was higher than that observed at 100 and $125 \mathrm{rpm}$, but the enzyme production was reduced, indicating that the increased biomass is not directly related to the enzyme production. It is known that the enzyme production is affected by the fungal morphology as well as the influence of agitation on this morphology, what can explain the result obtained for Muscodor sp. The production of phytase by Aspergillus niger under submerged fermentation was increased with stirring speed from 150 to $300 \mathrm{rpm}$. Moreover, the fungal morphology was influenced by the stirring with small pellets and tangles prevailing in the cultures at $150 \mathrm{rpm}$, while free filamentous form was obtained at $300 \mathrm{rpm}$ [27].

The optimum temperature for the production of phytase by Muscodor sp. was $30^{\circ} \mathrm{C}$ coinciding with the best temperature for the fungal growth as previously determined in our laboratory. Under this temperature the enzymatic production was 2-times higher than that observed at $25^{\circ} \mathrm{C}$. At $35^{\circ} \mathrm{C}$ the enzyme production decreased $20 \%$

\begin{tabular}{cc} 
Table 2. Additional carbon sources for phytase production by Muscodor sp. \\
\hline Carbon Source & Phytase Activity (U/mg) \\
\hline Rye Flour & 2.60 \\
Wheat Bran & 4.10 \\
Sugarcane Bagasse & 2.30 \\
Soybean & 1.50 \\
Oat & 1.30 \\
Corn Starch & 1.10 \\
\hline
\end{tabular}



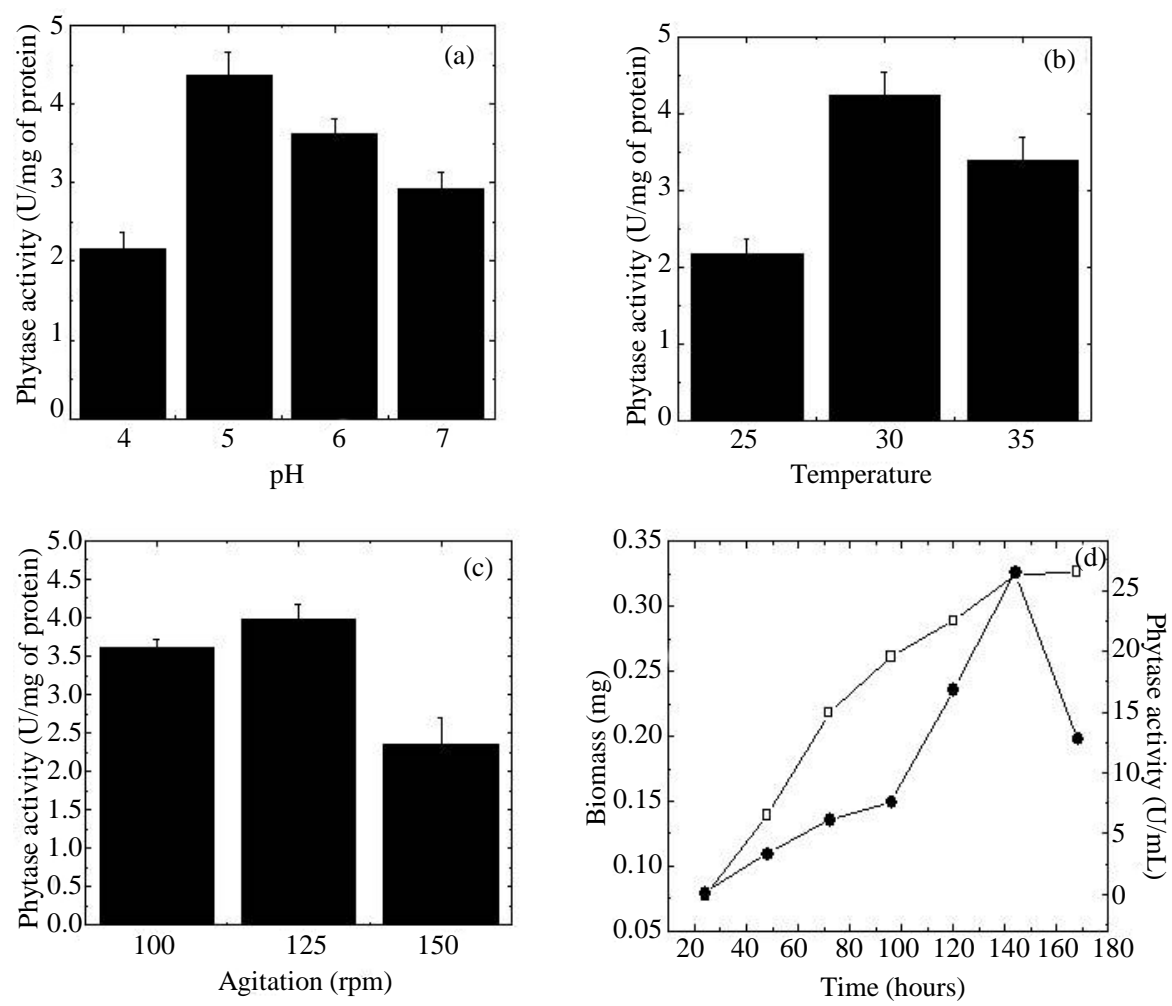

Figure 2. Influence of the initial $\mathrm{pH}$ of the culture medium (a), temperature of culture incubation (b), orbital agitation (c) and time of incubation (d) on phytase production by the endophytic fungus Muscodor sp. Symbols: $(\bullet)$ phytase activity; ( $\square$ ) dried biomass.

if compared to $30^{\circ} \mathrm{C}$ (Figure 2(c)). Several studies have investigated the optimum temperature for reaction of the phytase and phytase reported with optimal activity between $40^{\circ} \mathrm{C}$ and $60^{\circ} \mathrm{C}$, such as those obtained for the fungi $A$. fumigatus and $A$. niger NRRL 3135, with optimal activity at $37^{\circ} \mathrm{C}$ [28] and $55^{\circ} \mathrm{C}$ [29], respectively. However, phytases from Aerobacter aerogenes and Candida krusei WZ-001 showed optimum temperatures of $25^{\circ} \mathrm{C}$ and $40^{\circ} \mathrm{C}$ respectively [30] [31]. Thus, this demonstrates that these enzymes can act on various temperatures can be applied in industrial processes which require low or high temperatures.

\subsection{Kinetic of Phytase Production by Muscodor sp.}

The production of phytase by Muscodor sp. as function of incubation period was evaluated according to the parameters previously established: temperature of $30^{\circ} \mathrm{C}, \mathrm{pH} 5.0$, agitation at $125 \mathrm{rpm}$. The maximum phytase activity $(26.51 \mathrm{U} / \mathrm{mg}$ ) was achieved at $144 \mathrm{~h}$ of fermentation (Figure 2(d)). This period for enzyme production was minor than that mentioned for production of phytase by Rhodotorula mucilaginosa JMUY [32]. On the other hand, it was higher than that observed for enzyme production by Rhizopus microsporus var. microsporus [13], by Aspergillus niger CFR 335 and by Aspergillus ficuum SGA [33].

Under optimized parameters of cultivation $\left(30^{\circ} \mathrm{C}\right.$, initial pH 5.0, $125 \mathrm{rpm}$ for $\left.144 \mathrm{~h}\right)$, the specific activity of the phytase produced by the endophytic Muscodor sp. increased 11.32 times (from $2.34 \mathrm{U} / \mathrm{mg}$ to $26.51 \mathrm{U} / \mathrm{mg}$ ).

\subsection{Enzyme Stability}

The stability of Muscodor sp. phytase was evaluated after storage in $100 \mathrm{mM}$ citrate buffer (pH 3.0, 4.0, 5.0 and 6.0) for $1 \mathrm{~h}$ at $25^{\circ} \mathrm{C}$ (Figure 3(b)). At pH 5.0, it was observed maximal enzyme stability, but at pH 4.0 and 6.0, the enzyme activity was $20 \%-30 \%$ from that observed at $\mathrm{pH} 5.0$. The enzyme activity was fully inhibited at $\mathrm{pH}$ 3.0. Increase in the $\mathrm{pH}$ value reduced the phytase stability (data not shown). The $\mathrm{pH}$ stability is an important characteristic that should be considered aiming the phytase application. Efforts have been done to obtain enzymes with a wide $\mathrm{pH}$ range of stability as, for example, the recombinant phytases from Aspergillus japonicus 

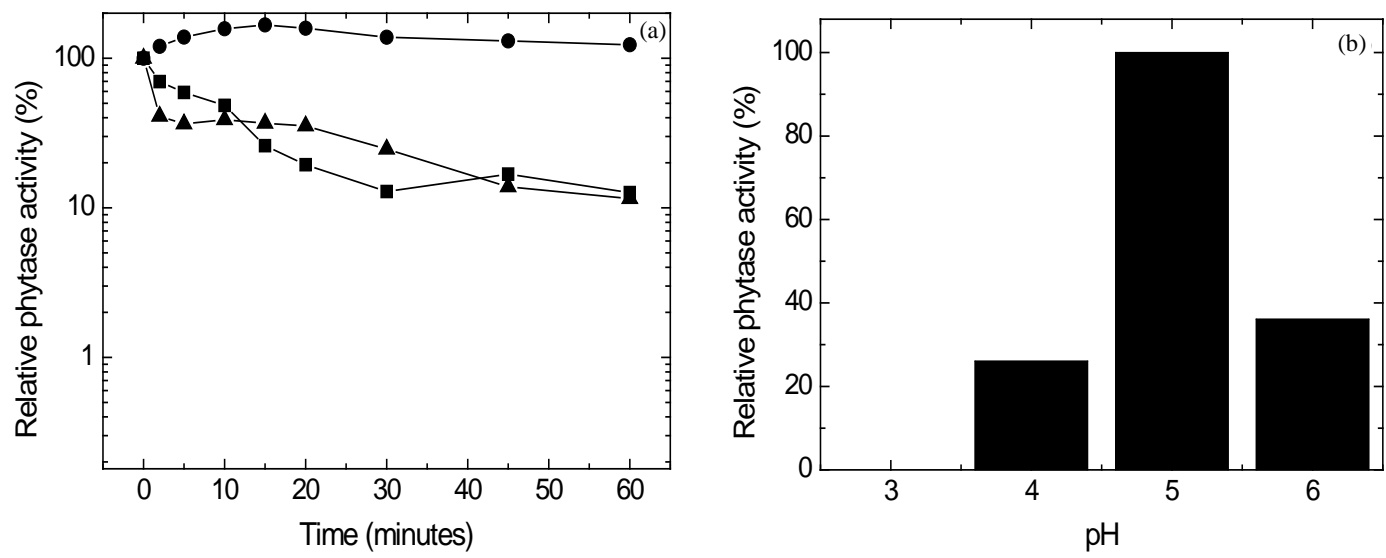

Figure 3. Thermal stability (A) and pH stability (B) of phytase produced bythe endophytic fungus Muscodor sp. For pH stability, partially purified extract was also used, but with an activity amount of 7.36 U/mg (100\% relative activity).

BCC18313 and Aspergillus niger BCC 18081 [34]. Phytase II of Aspergillus niger was stable from pH 3.5 to 9.0 at room temperature over $12 \mathrm{~h}$ [35]. Other studies show that phytase I of Monascus was stable at pH 5.5 - 6.5 and phytase II had a better stability from $\mathrm{pH} 6.0$ to 7.0 [36].

Another important aspect that has technological importance is the thermal stability. The Muscodor sp. phytase was fully stable at $40^{\circ} \mathrm{C}$ through the period analyzed. However, at $50^{\circ} \mathrm{C}$ and $60^{\circ} \mathrm{C}$ the enzyme stability was reduced with half-life $\left(\mathrm{T}_{1 / 2}\right)$ of $10 \mathrm{~min}$ and $1.5 \mathrm{~min}$, respectively (Figure 3(a)). Most microbial phytases reported in the literature has shown similar stability at temperatures from $45^{\circ} \mathrm{C}$ to $55^{\circ} \mathrm{C}$ [37]. However, according to Casey and Walsh [38], most fungal characterized phytases is stable at temperatures in the range from $30^{\circ} \mathrm{C}-60^{\circ} \mathrm{C}$.

The enzyme produced by Aspergillus fumigatus was inactivated only at $70^{\circ} \mathrm{C}$ [39]. The phytase produced by biofilm $R$. microsporus var. microsporus purified was completely stable at temperatures of $30^{\circ} \mathrm{C}$ and $40^{\circ} \mathrm{C}$ for $120 \min [13]$.

\subsection{Influence of Different Compounds on Phytase Activity}

The influence of different compounds on the phytase activity is presented in the Table 3 . The phytase produced by Muscodor sp. was totally inhibited by EDTA, $\mathrm{K}^{+}, \mathrm{Mg}^{2+}, \mathrm{Zn}^{2+}, \mathrm{Ca}^{2+}$ and urea (data not shown), and relatively inhibited by $\mathrm{Na}^{+}, \mathrm{Hg}^{2+}, \mathrm{Cu}^{2+}, \mathrm{Al}^{3+}, \mathrm{Fe}^{2+}$. On the other hand, in presence of $\mathrm{FeCl}_{3} 86 \%$ of phytase activity was maintained. Phytase produced by Aspergillus niger was also inhibited by $\mathrm{Cu}^{2+}, \mathrm{Zn}^{2+}, \mathrm{Hg}^{2+}$ and $\mathrm{Fe}^{2+}$ [8]. The activity of phytase from Candida krusei WZ-001 was completely inhibited by $\mathrm{Zn}^{2+}$ and strongly inhibited by $\mathrm{Mg}^{2+}$, but the increase of the concentration of $\mathrm{Fe}^{2+}(5 \mathrm{mM})$ resulted in recovery of phytase activity [30] [31]. Increasing the concentration of sodium, the enzyme activity from Muscodor sp. was drastically inhibited. Ullah, Sethumadhavan and Mullaney [40] reported that $500 \mathrm{mM} \mathrm{NaCl}$ had an inhibitory effect on the activity of phytase from Aspergillus niger.

Some phytases can be inhibited by metal ions, but it is difficult to determine whether inhibition is a result of metal binding to the enzyme or training complex phytic acid-poorly soluble ion. The formation of precipitated by the addition of $\mathrm{Fe}^{2+}$ and $\mathrm{Fe}^{3+}$ in the enzymatic assay suggests that there is a reduction in the concentration of active substrate complex of phytic acid formation poorly-soluble Fe [41]. Maenz, Engele-Schaan, Newkirk and Classen [42] evaluated the inhibitory potential at neutral $\mathrm{pH}$ of various minerals on the activity of microbial phytases and described the following order of inhibition: $\mathrm{Zn}^{2+}>\mathrm{Fe}^{2+}>\mathrm{Mn}^{2+}>\mathrm{Fe}^{3+}>\mathrm{Ca}^{2+}>\mathrm{Mg}^{2+}$. EDTA (ethylenediaminetetraacetic acid) is a chelating compound capable of forming stable complexes with various metal ions and most enzymes are adversely affected by this compound reducing the catalytic activity [43].

\section{Conclusion}

The endophytic fungus Muscodor sp. was the best phytase producer among all fugal strains analyzed and the enzyme production was affected by different parameters in the culture conditions. The high levels of enzyme production was obtained using wheat bran as carbon source, an interesting alternative with low cost for phytase 
Table 3. Effect of different compounds on Muscodor sp. phytase activity.

\begin{tabular}{cc}
\hline Compounds (1 $\mathbf{~ m M})$ & Relative activity (\%) \\
\hline Without & 100 \\
$\mathrm{NaCl}$ & 11.75 \\
$\mathrm{AlCl}_{3}$ & 49.9 \\
$\mathrm{CuCl}_{2}$ & 42.77 \\
$\mathrm{CuSO}_{4} \cdot 5 \mathrm{H}_{2} \mathrm{O}$ & 40.07 \\
$\mathrm{FeCl}_{3}$ & 86.12 \\
$\mathrm{HgCl}_{2}$ & 26.97 \\
\hline
\end{tabular}

$100 \%$ relative activity $=5.19 \mathrm{U} / \mathrm{mg}$ of protein.

production. After culture conditions optimization, the enzyme production was increased 11 -folds and the enzyme in the crude extract presented interesting properties for a possible application in the future. Then, this is the first report on phytase production by an endophytic fungus, an interesting alternative source of phytases.

\section{Acknowledgements}

The authors sincerely thank the Coordination of Improvement of Higher Education Personnel (CAPES), FAPEMIG and CNPq and appreciate the financial support that makes the development of this work possible. The authors would also like to thank Professor Luis Henrique Souza Guimarães and all staff of the Microbiology Laboratory of the University of São Paulo (USP/Ribeirão Preto, SP, Brazil) for their cooperation and support during the experiments in his laboratory.

\section{References}

[1] Zuo, R., Chang, J., Yin, Q., Chen, L., Chen, Q., Yang, X., Zheng, Q., Ren, G. and Feng, H. (2010) Phytase Gene Expression in Lactobacillus and Analysis of Its Biochemical Characteristics. Microbiological Research, 165, 329-335. http://dx.doi.org/10.1016/j.micres.2009.06.001

[2] Ravindran, V., Selle, P.H., Ravindran, G., Morel, P.C.H., Kies, A.K. and Bryden, W.L. (2001) Microbial Phytase Improves Performance, Apparent Metabolizable Energy, and Ileal Amino Acid Digestibility of Broilers Fed a LysineDeficient Diet. Poultry Science, 80, 338-344. http://dx.doi.org/10.1093/ps/80.3.338

[3] Sandberg, A.S. and Andlid, T. (2002) Phytogenetic and Microbial Phytases in Human Nutrition. International Journal of Food Science \& Technology, 37, 823-833. http://dx.doi.org/10.1046/j.1365-2621.2002.00641.x

[4] Turner, B.L. and Leytem, A.B. (2004) Phosphorus Compounds in Sequential Extracts of Animal Manures: Chemical Speciation and a Novel Fractionation Procedure. Environmental Science \& Technology, 38, 6101-6108. http://dx.doi.org/10.1021/es0493042

[5] Singh, B., Kaur, P. and Satyanarayana, T. (2006) Fungal Phytases for Improving the Nutritional Status of Foods and Combating Environmental Phosphorus Pollution. In Chauhan, A.K., Verma, A. (eds.) (2006) Microbes: Health and Environment. IK International Publishers, New Delhi, 289-326.

[6] Kim, T., Mullaney, E.J., Porres, J.M., Roneker, K.R., Crowe, S., Rice, S., Ko, T., Ullah, A.H.J., Daly, C.B., Welch, R. and Lei, X.G. (2006) Shifting the pH Profile of Aspergillus niger PhyA Phytase To Match the Stomach pH Enhances Its Effectiveness as an Animal Feed Additive. Applied and Environmental Microbiology, 72, 4397-4403. http://dx.doi.org/10.1128/AEM.02612-05

[7] Cousins, B. (1009) Enzimas na nutrição de aves. In: Concórdia, S.C., Ed., Simpósio internacional ACAV EMBRAPA sobre nutrição de aves, EMBRAPA-CNPSA, Concórdia, 118-132.

[8] Dvoráková, J., Volfová, O. and Kopecký, J. (1998) Characterization of Phytase Produced by Aspergillus niger. Folia Microbiologica, 42, 349-352. http://dx.doi.org/10.1007/BF02816948

[9] Lee, S.H., Cho, J., Bok, J., Kang, S., Choi, Y. and Lee, P.C. (2015) Characterization, Gene Cloning, and Sequencing of a Fungal Phytase, phyA, from Penicillium oxalicum PJ3. Preparative Biochemistry and Biotechnology, 45, 336-347. http://dx.doi.org/10.1080/10826068.2014.923446

[10] Xavier Salmon, D.N., Piva, L.C., Binati, R.L., Rodrigues, C., Vandenbergue, L.P., Soccol, C.R. and Spier, M.R. (2012) A Bioprocess for the Production of Phytase from Schizophyllum commune: Studies of Its Optimization, Profile of Fermentation Parameters, Characterization and Stability. Bioprocess and Biosystems Engineering, 35, 1067-1079. http://dx.doi.org/10.1007/s00449-012-0692-6 
[11] Rani, R. and Ghosh, S. (2011) Production of Phytase under Solid-State Fermentation Using Rhizopus oryzae: Novel Strain Improvement Approach and Studies on Purification and Characterization. Bioresource Technology, 102, 1064110649. http://dx.doi.org/10.1016/j.biortech.2011.08.075

[12] Zhang, G.Q., Dong, X.F., Wang, Z.H., Zhang, Q., Wang, H.X. and Tong, J.M. (2010) Purification, Characterization, and Cloning of a Novel Phytase with Low pH Optimum and Strong Proteolysis Resistance from Aspergillus ficuum NTG-23. Bioresource Technology, 101, 4125-4131. http://dx.doi.org/10.1016/j.biortech.2010.01.001

[13] Sato, V.S., Jorge, J.A., Oliveira W.P., Souza, C.R.F. and Guimarães, L.H.S. (2014) Phytase Production by Rhizopus microsporus Var. Microsporus Biofilm: Characterization of Enzymatic Activity after Spray Drying in Presence of Carbohydrates and Nonconventional Adjuvants. Journal of Microbiology and Biotechnology, 24, 177-187. http://dx.doi.org/10.4014/jmb.1308.08087

[14] Pandey, A., Szakacs, G., SoccoL, C.R., Rodriguez-Leon, J.A. and Soccol, V.T. (2001) Production, Purification and Properties of Microbial Phytases. Bioresource Technology, 77, 203-214.

[15] Silva, L.T., Moreira, K.A., Porto, T.S. and Porto, A.L.F. (2010) Produção de fitase a partir de resíduos agroindustriais em fermentação no estado sólido utilizando fungos do gênero Aspergillus. Jepex 2010, Universidade Federal Rural de Pernambuco, Recife.

[16] Gulati, H.K., Chadha, B.S. and Saini, H.S. (2007) Production of Feed Enzymes (Phytase and Plant Cell Wall Hydrolyzing Enzymes) by Mucorindicus MTCC 6333: Purification and Characterization of Phytase. Folia Microbiologica, 52, 491-497. http://dx.doi.org/10.1007/BF02932109

[17] Bradford, M.M. (1976) A Rapid and Sensitive Method for the Quantitation of Microgram Quantities of Protein Utilizing the Principle of Protein-Dye Binding. Analytical Biochemistry, 72, 248-254. http://dx.doi.org/10.1016/0003-2697(76)90527-3

[18] Strobel, G. (2006) Muscodor albus and Its Biological Promise. Journal of Industrial Microbiology \& Biotechnology, 33, 514-522. http://dx.doi.org/10.1007/s10295-006-0090-7

[19] Mitchell, A.M., Strobel, G.A., Hess, W.M., Vargas, P.N. and Ezra, D. (2008) Muscodor crispans, a Novel Endophyte from Ananas ananassoides in the Bolivian Amazon. Fungal Diversity, 31, 37-43. http://dx.doi.org/10.1099/mic.0.032540-0

[20] Ehrlich, K.C., Montalbano, B.G., Mullaney, E.J., Dischinger, H.C. and Ullah, A.H. (1994) An Acid-Phosphatase from Aspergillus ficuumhas Homology to Penicillium chrysogenum phoA. Biochemical and Biophysical Research Communications, 204, 63-68.

[21] Mullaney, E.J., Daly, C.B. and Ullah, A.H. (2000) Advances in Phytase Research. Advances in Applied Microbiology, 47, 157-199. http://dx.doi.org/10.1016/S0065-2164(00)47004-8

[22] Bhavsar, K., Kumar, V.R. and Khire, J.M. (2011) High Level Phytase Production by Aspergillus niger NCIM 563 in Solid State Culture: Response Surface Optimization, Up-Scaling, and Its Partial Characterization. Journal of Industrial Microbiology \& Biotechnology, 38, 1407-1417. http://dx.doi.org/10.1007/s10295-010-0926-z

[23] Roopesh, K., Ramachandran, S., Nampoothiri, K.M., Szakacs, G. and Pandey, A. (2006) Comparison of Phytase Production on Wheat Bran and Oilcakes in Solid-State Fermentation by Mucor racemosus. Bioresource Technology, 97, 506-511. http://dx.doi.org/10.1016/j.biortech.2005.02.046

[24] Casey, A. and Walsh, G. (2003) Purification and Characterization of Extracellular Phytase from Aspergillus niger ATCC 9142. Bioresource Technology, 86, 183-188. http://dx.doi.org/10.1016/S0960-8524(02)00145-1

[25] Spier, M.R., Fendrich, R., Almeida, P., Noseda, M., Greiner, R., Konietzny, U., Woiciechowski, A., Soccol, V. and Soccol, C.R. (2010) Phytase Produced on Citric Byproducts: Purification and Characterization. World Journal of Microbiology and Biotechnology, 27, 267-274. http://dx.doi.org/10.1007/s11274-010-0455-y

[26] Vohra, A. and Satyanarayana, T. (2003) Phytases: Microbial Sources, Production, Purification, and Potential Biotechnological Applications. Critical Reviews in Biotechnology, 23, 29-60. http://dx.doi.org/10.1080/713609297

[27] Papagianni, M., Psomas, S.K., Batsilas, L., Paras, S.V., Kyriakidis, D.A. and Liakopouloukyriakides, M. (2001) Xanthan Production by Xanthomonas campestris in Batch Cultures. Process Biochemistry, 37, 73-80. http://dx.doi.org/10.1016/S0032-9592(01)00174-1

[28] Pasamontes, L., Haiker, M., Wyss, M., Tessier, M. and Van Loon, A.P. (1997) Gene Cloning, Purification, and Characterization of a Heat-Stable Phytase from the Fungus Aspergillus fumigatus. Applied and Environmental Microbiology, 63, 1696-1700.

[29] Howson, S.J. and Davis, R.P. (1983) Production of Phytate-Hydrolyzing Enzyme by Some Fungi. Enzyme and Microbial Technology, 5, 377-382. http://dx.doi.org/10.1016/0141-0229(83)90012-1

[30] Greaves, M.P., Anderson, G. and Webley, D.M. (1967) The Hydrolysis of Inositol Phosphates by Aerobacter aerogenes. Biochimica et Biophysica Acta, 132, 412-418. http://dx.doi.org/10.1016/0005-2744(67)90160-X

[31] Quan, C.S., Fan, S.D., Zhang, L.H., Wang, Y.J. and Ohta, Y. (2002) Purification and Properties of a Phytase from 
Candida krusei WZ-001. Journal of Bioscience and Bioengineering, 94, 419-425.

[32] Yu, P., Wang, X.T. and Liu, J.W. (2015) Purification and Characterization of a Novel Cold-Adapted Phytase from Rhodotorula mucilaginosa Strain JMUY14 Isolated from Antarctic. Journal of Basic Microbiology, 55, 1029-1039. http://dx.doi.org/10.1002/jobm.201400865

[33] Shivanna, G.B. and Venkateswaran, G. (2014) Phytase Production by Aspergillus niger CFR 335 and Aspergillus ficuum SGA 01 through Submerged and Solid-State Fermentation. The Scientific World Journal, 2014, 1-6. http://dx.doi.org/10.1155/2014/392615

[34] Promdonkoy, P., Tang, K., Sornlake, W., Harnpicharnchai, P., Kobayashi, R.S., Ruanglek, V., Upathanpreecha, T., Vesaratchavest, M., Eurwilaichtr, L. and Tanapongpipat, S. (2009) Expression and Characterization of Aspergillus Thermostable Phytases in Pichiapastoris. FEMS Microbiology Letters, 290, 18-24. http://dx.doi.org/10.1111/j.1574-6968.2008.01399.x

[35] Soni, S.K., Magdum, A. and Khire, J.M. (2010) Purification and Characterization of Two Distinct Acidic Phytases with Broad pH Stability from Aspergillus niger NCIM 563. World Journal of Microbiology and Biotechnology, 26, 2009-2018. http://dx.doi.org/10.1007/s11274-010-0385-8

[36] Tadashi, N., Satoshi, K., Tadanori, Y., Hideharu, A., Yoko, K., Seiji, S. and Keiichi, Y. (2001) Phytase Having a Low Michaelis Constant for Phytic Acid from Monascus. United States Patent No. 6261592. http://www.freepatentsonline.com/6261592.html

[37] Boyce, A. and Walsh, G. (2007) Purification and Characterization of an Acid Phosphatase with Phytase Activity from Mucor hiemalis Wehmer. Journal of Biotechnology, 132, 82-87. http://dx.doi.org/10.1016/j.jbiotec.2007.08.028

[38] Casey, A. and Walsh, G. (2004) Identification and Characterization of a Phytase of Potential Commercial Interest. Journal of Biotechnology, 110, 313-322. http://dx.doi.org/10.1016/j.jbiotec.2004.03.001

[39] Woodzinski, R.J. and Ullah, A.H.J. (1996) Biochemical Characterization of Cloned Aspergillus fumigatus Phytase (PhyA). Advances in Applied Microbiology, 42, 263-302.

[40] Ullah, A.H.J., Sethumadhavan, K. and Mullaney, E.J. (2008) Unfolding and Refolding of Aspergillus niger PhyB Phytase: Role of Disulfide Bridges. Journal of Agricultural and Food Chemistry, 56, 8179-8183. http://dx.doi.org/10.1021/jf8013712

[41] Konietzny, U., Greiner, R. and Jany, K.D. (1995) Purification and Characterization of a Phytase from Spelt. Journal of Food Biochemistry, 18, 165-183. http://dx.doi.org/10.1111/j.1745-4514.1994.tb00495.x

[42] Maenz, D.D., Engele-Schaan, C.M., Newkirk, R.W. and Classen, H.L. (1999) The Effect of Minerals and Mineral Chelators on the Formation of Phytase-Resistant and Phytase-Susceptible Forms of Phytic Acid in Solution and in a Slurry of Canola Meal. Animal Feed Science and Technology, 81, 177-192. http://dx.doi.org/10.1016/S0377-8401(99)00085-1

[43] Kerovuo, J., Lauraeus, M., Nurminen, P., Kalkkinen, N. and Apajalahti, J. (1998) Isolation, Characterization, Molecular Gene Cloning, and Sequencing of a Novel Phytase from Bacillus subtilis. Applied and Environmental Microbiology, 64, 2079-2085. 